\title{
Transnational Investments of the Tunisian Diaspora: Trajectories, Skills Accumulation and Constraints
}

\author{
Sylvia Garcia Delahaye and Gabriela Tejada
}

\begin{abstract}
This chapter is based on recent empirical data on Tunisians living in Switzerland. It focuses on their migration pathways and experiences, and it examines their propensity to engage in entrepreneurial and business activities in their home country. Despite the hopes generated by the revolution of 2011, many people in Tunisia, especially young males from disadvantaged regions, have not enjoyed the positive changes in employment opportunities and professional prospects. This has led to them emigrating to Europe to ensure an income for themselves and their families back in Tunisia. An online survey accompanied by follow-up interviews enabled us to observe the experiences of Tunisian diaspora entrepreneurs and their current and potential future transnational business and investment activities. This chapter shows how the internationalization and accumulation of networks and skills by Tunisians, resulting from the multiple destinations they traversed before arriving in Switzerland, has influenced their professional capacities and their business and entrepreneurial projects in Tunisia. Tunisians feel a strong motivation to contribute to the development process in their home country, and they tend to invest and open businesses in their villages of origin. Several enablers and obstacles that influence their actions are observed. The conclusions include a number of policy recommendations based on the experiences and aspirations of these Tunisians.
\end{abstract}

\section{Introduction}

The current international migration context, influenced by the intensity of globalization, innovative forms of interconnections and the power of networks, the transnationalisation of processes (Faist et al. 2011; Portes and Yiu 2013), and continuing disparities in opportunities for progress and development among countries and regions, has given rise

S. G. Delahaye · G. Tejada $(\bowtie)$

Cooperation and Development Center (CODEV), Ecole Polytechnique Fédérale de Lausanne

(EPFL), Lausanne, Switzerland

e-mail: sylvia.garcia@graduateinstitute.ch; gabriela.tejada@epfl.ch 
to new actors and new dynamics in international relations. Specifically, in the area where migration and development converge, diasporas (Cohen 1997; Sheffer 1986) or transnational communities (Wickramasekara 2010) have gained relevance as the result of an increasing recognition of the actual and potential benefits that their interventions have for both the countries of origin and those of destination.

The focus on the actions of diasporas in their different forms and effects has led to significant growth in both the body of academic work and political discussion over the past two decades or more. Four elements characterize the current approach. Firstly, the paradigm of brain gain, which seeks to reduce the negative effects, and maximize the potential benefits of the movement of the migrants' human capital, is reliably anchored in an understanding of the links between migration and development. Secondly, although the "diaspora option" — understood as the capitalisation of diaspora resources for home country development (Meyer 2001; Newland 2010; Tejada 2012; Varzari et al. 2014) has become a central issue on national and international cooperation agendas, the crucial challenge is to find effective ways to move forward from administrative provisions, such as mapping studies or inventories of skills, to the definition of road maps and applicable mechanisms that can enable sustainable cooperation with diasporas (Meyer 2014; Agunias and Newland 2012). Thirdly, the alternative of a return of competences through connections and remote collaborative interventions often complements the resurgent interest in the physical return of human capital (Tejada et al. 2014; Siddiqui and Tejada 2014). Lastly, since migration effects are mostly felt at a local level, local public authorities have become important key players in the implementation of cooperation instruments together with their diasporas (IOM and UNDP 2015; JMDI 2015).

Several recent examples show the determination of countries to tap into the resources and expertise of their diasporas by establishing programmes and tangible instruments to engage them in actions that will eventually benefit their localities of origin. One such case is the recent creation of associations of Moldovan natives in a number of villages and towns in Moldova, which have stimulated a powerful "giving-back" attitude. ${ }^{1}$ Another example is the establishment of the Diasporas Affairs Bureau in Ghana in 2014 to foster collaboration with the diaspora in accordance with national strategic plans. The Mexican "Strategy of financial inclusion of migrants", promotes investments by Mexicans abroad in business or entrepreneurial projects in rural areas of Mexico. Finally, examples in the Caribbean region show how a number of countries are currently addressing the development role of diasporas in their national development plans. Some have also introduced diaspora investments programmes that provide business and mentoring support to diaspora members; one such example is IntEnt in Surinam (Minto-Coy 2016b).

\footnotetext{
${ }^{1}$ This was implemented with the support of the Migration and Local Development Programme (MiLD) of UNDP office in Chisinau. http://www.md.undp.org/content/moldova/en/home/operations/projects/ inclusive_growth/integrated-migration-local-development-project-/ (retrieved on 18 July 2016).

${ }^{2}$ http://www.financierarural.gob.mx (retrieved on 18 July 2016).
} 
In the light of these considerations, this chapter is based on recent empirical data on Tunisians living in Switzerland. It focuses on their migration trajectories (understood as the mobility process that covers the different itineraries that migrants follow and which are influenced by both personal and contextual circumstances), living conditions, competences and resources, and it discusses their propensity to engage in entrepreneurial and business activities in their home country. Despite the hopes generated by the revolution of 2011 that ended the repressive rule of President Ben Ali, the positive changes in terms of employment opportunities and professional prospects in Tunisia have not been evident to many people, especially young men in disadvantaged regions. This has resulted in these people emigrating to Europe in order to ensure an income for themselves and their families back in Tunisia.

An online survey supplemented by follow-up interviews enabled us to outline the parameters of Tunisian diaspora entrepreneurs and their current and potential future transnational business and investment activities. ${ }^{3}$ By examining their migration routes, we saw that Tunisians follow multiple paths before they arrive in Switzerland. At every stage, they establish social links and accumulate considerable social capital [understood as "the ability of actors to secure benefits by virtue of membership in social networks or other social structures" (Portes 1998: 6)], and this influences their professional capacities and their business and entrepreneurial projects in Tunisia. We observe how the spontaneous and individually-based nature of Tunisian diaspora investments and business creation is mainly centred on personal determination, and we also look at how it remains independent of the new policy framework supporting diaspora endeavours. This is partly due to a lack of trust in public policies linked to the Ben Ali regime, and ongoing corruption in the country.

The purpose of the original contribution of this chapter is twofold. First of all, it provides original data on the migration trajectories and host-country experiences of Tunisians living in Switzerland, collected during a time of political transition in Tunisia. Secondly, it provides us with a better understanding of the mechanisms that diasporas use to contribute to development, by looking at migrants' investments and the influence that their foreign-earned skills has on their motivation to start a business in their home country, and it also examines the enablers and obstacles that influence their endeavours.

\footnotetext{
${ }^{3}$ The data were collected during 2013 as part of a mapping study carried out for the CTRS for Development Project commissioned by the Swiss Agency for Development and Cooperation (SDC). The overall aim of the project is to encourage the implementation of mechanisms that can capitalize on the social and financial resources, capacities and skills of the Tunisian community residing in Switzerland. http://www.ctrs.ch/ (retrieved on 18 July 2016).
} 


\section{Diaspora Home-Country Investments in the Migration and Development Nexus}

Within the migration and development nexus, the emphasis on financial remittances as a form of migrants' capital and savings flow has dominated the academic literature on diaspora home-country investments (Agunias 2006; Ratha 2009; Vaaler 2011). Elo and Riddle (2016) refer to diaspora investments as cross-border businessdirected investments flows transacted by diaspora in their home country. Diasporas investments stretch beyond remittances and are considered as quite heterogeneous in their forms, origins, generators and effects. Empirical studies show how both investing capital in existing businesses and/or setting up new ventures in the regions of origin are becoming popular as ways for diasporas to stimulate economic development in their home countries (Portes et al. 2002, Brinkerhoff 2008; Newland and Tanaka 2010). A new stream of research has tried to find out more about what motivates diasporas to invest in their country of origin, either as individuals or in groups, and to identify the elements that determine why the level of investment and entrepreneurial commitment diverges substantially from one country to another (Crush et al. 2013; Nielsen and Riddle 2007; Nkongolo-Bakenda and Chrysostome 2013; Elo and Riddle 2016). Studies propose focussing on contextual factors in local contexts in the home countries as well as on the social and emotional aspects that influence the decision-making process of migrants. For example, Elo and Riddle (2016) see the investment drivers of individuals as involving aspects related to the investor's life cycle and political and sociocultural settings. In a similar vein, Galetto (2011) concludes that it is the interaction among diverse factors that influences the level and type of engagement by diaspora investors and entrepreneurs.

At a conceptual level, the diaspora is seen as a group united by a common ethnic identity and a collective relationship of solidarity towards the country of origin (Bordes Benayoun and Schnapper 2006), which is capable of simultaneously making valuable and creative contributions to the country of origin and to the country of destination (Cohen 1997; Sheffer 1986). The simultaneous presence or transnational identity of the diaspora (Vertovec 2001; Portes 2001; Levitt and Glick-Schiller 2004) results in their behaviour and their entrepreneurial projects being affected by the incentives and conditions of the multiple national contexts in which they act. Moreover, recent studies have observed that the social capital that migrants have accumulated through multiple migratory paths also influences their actions and determines the risks that they face and their opportunities to invest and set up businesses in their countries of origin (Smith 2011). As such, social capital is seen as encompassing the individual's obligations and expectations in the form of resources or capital invested in someone for future use (Bourdieu 1986).

In order to understand the motivations and specific determinants that favour investment by the diaspora, it is important to observe the differences in their nature, in other words whether they are individual or collective (Elo and Riddle 2016). On the one hand, the aim of the actions of individual migrant investors or those of members of families is to create a sustainable livelihood for themselves and to improve their 
quality of life. On the other hand, the collective actions of diaspora organisations are motivated by a common interest to contribute to the development of their communities of origin, mainly through social infrastructure projects. While the former are spontaneous and informal on occasions, the community projects of the latter are based on formal structures and operate as diaspora associations (Tejada 2012).

At a policy level, several countries have implemented schemes to assist diaspora entrepreneurship and promote productive investments for the benefit of the broader society. The Mexican Three-for-One Programme ${ }^{4}$ is one example of this; the scheme matches every dollar from a migrant Home Town Association (HTA) with one dollar each from the federal, state, and municipal governments, channelling resources to the execution of projects that have a social impact in the communities of origin. The case in point of the Mexican HTAs shows that a higher level of organization translates into a greater capacity to reach institutional support (SEDESOL 2014). A similar scheme implemented by the government of Moldova, known as the Pare $1+1$ Programme, ${ }^{5}$ matches the investments of individual migrants and is intended to create jobs and businesses in local communities that have been hard hit by emigration. In the Caribbean region, even though several countries have started to implement policies that facilitate diaspora engagement in various forms, the private sector has already been involved for a long time, with diasporas acting as investors, entrepreneurs and partners in their international businesses (Minto-Coy 2016b). These and other examples show how the organisations that support diaspora entrepreneurship play various roles, either by providing contacts with actors linked to the businesses or else by establishing strategic associations that offer business opportunities with a long-term impact (Newland and Tanaka 2010; Elo and Riddle 2016). Even though governments increasingly recognise the value of the entrepreneurial and investment actions of the diaspora, experience has shown that both a peaceful and a stable national context with basic infrastructure, and a series of supporting public policies are necessary elements to promote them. As Portes and Yiu (2013) rightly point out, the socio-political context of the countries is decisive when determining the structure of the opportunities that encourage migrants to use their talent and motivates them to contribute to the socio-economic advancement of their place of origin.

\section{Tunisian Migration and Country Policies on Migration and Development in the Post-revolution Context}

Tunisia has been a major emigration country within the Mediterranean region for many years. According to estimates from the Office of Tunisians Abroad (OTE), some 1.2 million Tunisians live overseas out of a total population of over 11 million. $^{6}$

\footnotetext{
${ }^{4}$ http://www.ime.gob.mx/ca/programa-3x 1

${ }^{5} \mathrm{http}$ ///finantare.gov.md/ro/content/programul-de-atragere-remitentelor-economie-pare-11

${ }^{6}$ The last available data are from 2012 only http://www.ote.nat.tn (retrieved 11 July 2016).
} 
Over the last number of decades, Tunisian emigration has primarily been dominated by labour migration, with the traditional destinations being the countries of Western Europe and those in the Maghreb region. Today, the main host countries in Europe are France, Italy, Germany, Belgium-Luxembourg, and Switzerland. ${ }^{7}$

The poor performance of the domestic labour market and a deficient democratisation process are the main reasons for the persistence of labour emigration flows from Tunisia (Di Bartolomeo et al. 2010). The intensification of regular and irregular Tunisian emigration in the past few years is proof that the hopes raised during the January 2011 revolution have not been sufficient to build a source of revenue and counteract unemployment and the lack of professional opportunities. This situation mostly affects young Tunisians in disadvantaged regions who emigrate to Europe in search of opportunities that can provide them and their families with a better livelihood (Boubakri 2013). In more recent years, rising unemployment among tertiary-educated youth has led to new flows of students and high-skilled emigration, especially to Germany and North America. These people leave to improve their education and their professional prospects and they plan to eventually return to Tunisia once their migration project has been accomplished.

With regard to Switzerland as a destination country, the most recent data from the Swiss Federal Office for Migration (ODM) show that there were 7305 Tunisians living in Switzerland at the end of May 2016 (2893 women and $4412 \mathrm{men}$ ). ${ }^{8}$ In terms of location, the vast majority of these people tend to settle in urban French-speaking or bilingual regions. The main reasons why Tunisians emigrate to Switzerland are professional prospects, family reunification, further education, political oppression and a lack of opportunities in Tunisia; the emigrants hold various professional profiles and levels of education (Tejada and Garcia Delahaye 2014).

Before the revolution, the Tunisian government established a political strategy whose goal was to supervise the Tunisian diaspora and provide it with social assistance while strengthening cultural ties with Tunisians abroad, and encouraging investments and financial remittances. Furthermore, the establishment of an information system aimed at keeping Tunisians abroad abreast of developments in Tunisia functioned as a method of state control by the Tunisian state (Zekri 2004; Di Bartolomeo et al. 2010). After the country's first free elections in late 2011 and the adoption of a new constitution in early 2014, the local authorities were faced with new challenges to establish consequent strategies to manage emigration and promote stable connections with Tunisians abroad as a means of channelling migration for regional and national development. The creation of the Secretary of State for

\footnotetext{
${ }^{7}$ Other main destination countries outside Europe include Libya, the United Arab Emirates and Algeria in the Arab and Maghreb regions; and Canada and the USA in North America. http://www. ote.nat.tn (retrieved 11 July 2016).

${ }^{8}$ This total includes 7275 permanent residents and 30 total non-permanent residents. The total only includes people with Tunisian nationality and excludes those with double Tunisian-Swiss nationality. Swiss Federal Office for Migration; https://www.sem.admin.ch/sem/fr/home.html (data extracted on 18 July 2016).
} 
Migration and Tunisians Abroad (SEMTE) in $2011^{9}$ showed the special interest that the transitional government had in promoting the impact of diaspora resources for long-term sustainable development as a national priority. The purpose of SEMTE is to support the initiatives of migrant associations and reinforce links among Tunisian diaspora communities. Encouraging financial remittances [which amounts to 4.2\% of GDP (SEMTE 2013)] and promoting diaspora investments in the agriculture, industry and services sectors ${ }^{10}$ lie at the core of this strategy.

Other recent government efforts have focused on controlling and managing migration because of the increase in irregular migration flows. Some related policies include encouraging and regulating the recruitment of Tunisian nationals abroad and dissuading Tunisians from irregular migration through increased information and awareness-raising campaigns (Boubakri 2013). Another relevant policy issue is the Mobility Partnership signed by the Tunisian government and the European Union (EU) in 2014. This was established in the light of EU security concerns resulting from the Arab uprising and the potential threat of large-scale population movements or refugee crises (Seeberg 2014; Carrera et al. 2013). This policy framework regulates future cooperation, mainly within the area of migration with its controloriented component, but also in issues linked to migration and development.

Looking at how migration and development is approached from a host-country perspective, such as that of Switzerland, is important in terms of understanding the economic and political context that allows Tunisians to become productively involved in their country of origin. As Hercog (2014) has indicated, the institutional environment and policies of the migrants' host countries may play a crucial role in terms of migrants' opportunities to gain relevant expertise and to mobilise. Switzerland's international cooperation positions the migration and development nexus as a strategic objective of its development agenda, concretely through the Global Programme for Migration and Development of the Swiss Agency for Development and Cooperation (SDC), which seeks to reduce poverty in the countries of origin. Collaboration is based on the concept of partnership, aimed at reducing emigration pressures (Hercog 2014). Up to now, migration partnerships have been formalised with a handful of countries, including Tunisia. In Tunisia's case, the focus is on improving living conditions and employment opportunities by providing technical assistance within various areas. An important component of this cooperation is advising the Tunisian government about how to include diaspora communities in its development strategies.

Both SDC and SEMTE are very recent policies, and it is too early to assess their impact on enabling diaspora investments and business creation. Nevertheless, Tunisians in Switzerland engage in their home country through the systematic transfer of financial resources and the establishment of businesses there. However,

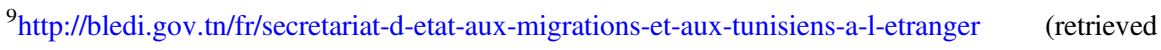
12 July 2016).

${ }^{10} \mathrm{http}: / /$ bledi.gov.tn (retrieved 12 July 2016).
} 
this engagement is mainly the result of individual entrepreneurial will and personal determination with no actual public-policy backing.

\section{Empirical Evidence of Tunisians in Switzerland}

The rest of the chapter draws on an analysis of the migration trajectories of Tunisians, their living experiences in Switzerland and the determinants of their contributions to their localities of origin. The data presented here were collected during 2013 using a primary on-line survey applied to members of the Tunisian community residing in Switzerland (TCRS). ${ }^{11}$ Qualified Tunisians had to be at least 18 years old. Respondents were asked both closed and open questions about their migration trajectories, their life conditions and experiences in Switzerland, their associative activities and their links with Tunisia, their future projects and their perceptions of their role in the development of their home country. They were asked to provide specific recommendations for both the Swiss and the Tunisian governments about the best ways to encourage diaspora contributions. The data were recorded, processed and analysed on a software platform. The survey was answered by 192 Tunisians. To complement this, 41 qualitative semi-structured face-to-face interviews were conducted. ${ }^{12}$ The primary results of the survey were used to select questions for the interview screening. The main themes of the interview screening were about the following aspects: personal migration itinerary, experiences in Switzerland, professional activity experience, ties with Tunisia and their potential impact in terms of Tunisia development projects. All the interviews were recorded. Each retranscription was analysed by focusing on the recurrence of the interviewees' experiences, perceptions and aspirations as potential actors of development in Tunisia and in Switzerland.

Both formal and informal channels were used to recruit the sample and these included: email invitations sent to representatives of Tunisian Associations and the Tunisian Embassy in Bern, who helped to distribute them; social networks (Facebook, LinkedIn, Twitter, etc.); distributing leaflets with information about the project at Arab cultural centres in various cities, etc. The data were collected between July and November 2013, during a period of difficult political transition that divided society according to political affiliations. This division was palpable in the political and social discussions of the time, and in the confronting emotional opinions that the members of the diaspora had about their perceptions of the role they should play in

\footnotetext{
${ }^{11}$ Based on residence status, this mainly comprised four groups: 1) people with dual Tunisian and Swiss nationality; 2) permanently resident Tunisians; 3) non-permanently resident Tunisians; 4) Tunisians with non-regular status and asylum seekers.

${ }^{12}$ Out of a total of 41 interviews, 27 were conducted with Tunisians who came from the first three groups mentioned above; 5 interviews were conducted with Tunisians who held non-regular status and/or were asylum seekers; and 9 additional interviews were conducted with representatives of Tunisian diaspora associations, the Tunisian Embassy in Bern, and the Tunisian-Swiss Chamber of Commerce and Industry.
} 
the development of their home country and the opportunities that they thought the post-revolutionary context might bring.

We need to take some limitations of the study into consideration when interpreting the data. Firstly, the short timeframe in which the data were collected meant there was an unbalanced representation of the main groups of members of Tunisian community residing in Switzerland included in our definition of target group. Secondly, the political situation in Tunisia during the course of the study had an emotional impact on the opinions and perceptions of Tunisians. It is therefore important to place the study within the political context of the transition in which it was completed. Accordingly, we need more studies in order to have a better overview of Tunisian groups living in Switzerland and their feelings and attitudes towards the changing context in Tunisia.

The following sections present some of the observations of the survey and some testimonies of the Tunisians who were interviewed.

\subsection{Migratory Paths}

Tunisians born abroad started to arrive in Switzerland back in the 1940s. The numbers increased during the early years of the twenty-first century, especially after 2010 with the onset of the crisis and the end of the Ben Ali regime. Regardless of the period of their arrival in Switzerland, the main reasons why people come are: professional opportunities (e.g. a job with an international organisation), family regrouping, studies, political oppression (especially during the Ben Ali regime) and the precariousness of life in Tunisia (particularly for migrants from less privileged social backgrounds). The analysis of the migratory paths of the members of the TCRS allows us to highlight three main themes related to the opportunities and investment possibilities of this community in Tunisia: the mobility and internationalisation of social networks, risk taking through migration, and a project to return.

The mobility and internationalisation of the social networks of the members of the TCRS are noteworthy elements within the context of their migratory paths. Indeed, the mobility of this community, which establishes itself in different countries and regions of the world before arriving in Switzerland, reveals multi-site life and family itineraries. These multi-site paths enable the development of social ties and the acquisition of skills (professional, technical and social) that come into play simultaneously in Switzerland and in Tunisia. These networks are not only favourable to migration but they also favour the development of professional careers and the implementation of investment and entrepreneurial projects through funding that is also multi-site (Cassarino 2000). The migratory paths are therefore influenced by the social relations of the members of the TCRS outside the country and not exclusively with Tunisians. With regard to the importance of social networks for the professional careers and development of investment or entrepreneurial projects, this involves all social and professional categories and includes students. 
Furthermore, the multi-site paths and accumulated networks and interconnections of diasporas also have a propensity to facilitate the growth and internationalisation of businesses from home countries. This is particularly beneficial for small and medium size companies from (small) developing countries that find it harder to identify new markets as part of their internationalisation endeavours, as shown by Minto-Coy (2016a, b) in their examples of the Caribbean diaspora.

"Risk taking" through migration is more significant among young males from more modest social backgrounds who support their families back in Tunisia by going to Europe. Their contribution takes the form of regular transfers of money to cover everyday expenses, improve the living conditions of the family and develop family businesses in Tunisia. It should be emphasised that these transfers are dominant in the accounts of migrants from poorer social backgrounds in contrast to the testimonies of those members of the TCRS who came from more middle- and upper-class backgrounds.

Switzerland has become the main country of attachment for permanent residents from all social classes. However, "permanent resident" status also offers the possibility of multi-site life and family trajectories. Indeed, this status is a guarantee of security - the security of being able to return to Switzerland-which is necessary for the development of personal, professional and family projects in other countries. Therefore, the migratory paths of permanently-resident Tunisians simultaneously reveal a search for personal and professional security as well as important social bonds in Switzerland and other countries. For this group in particular, "risk-taking" as part of a temporary project to return to Tunisia is weak and wilfully assessed.

In the accounts we gathered, there was very little mention of a project for a permanent return to Tunisia. This pattern relates to structural questions in Switzerland (the quality of life and professional opportunities) and in Tunisia (limited professional opportunities, the economic crisis and the instable political climate linked to the end of the dictatorship, the revolution and the transition to democracy) and to the effect of TCRS mobility. The career path, age, duration and residence permit of the Tunisians are some of the determining factors and reasons for remaining in Switzerland. For instance, the residence permit is an important factor of non-return to Tunisia for the "risk taking" group, as they probably wouldn't be entitled to come back to Switzerland with a work permit. Therefore, non-return to Tunisia does not result in a disengagement between this community and the country of origin. On the contrary, this engagement is tied to the living experience of the TCRS members in Switzerland and their attachment to Tunisia.

\subsection{Experiences in Switzerland}

The analysis of the situation and the living experiences of the members of the TCRS in Switzerland is essential to understanding the investment and entrepreneurial possibilities in Tunisia. Indeed, the mobilisation of resources by migrants does not depend solely on their personal profile, their training or their professional activity, 
but rather it depends equally on the environment and the opportunities offered by both the host country and the country of origin. To measure the experiences lived by Tunisians in Switzerland, it is important to observe their level of satisfaction with living conditions and learning, employment, investment and entrepreneurial opportunities in their host country. The factors of cultural and professional integration in Switzerland must also be taken into account, especially access to the jobs market, residency status and a sense of belonging.

\subsubsection{Degree of Satisfaction in Relation to Local Conditions}

Most of the participants believe that living conditions are better in Switzerland than in Tunisia in terms of salaries, professional and career opportunities, equal opportunities for men and women, the honesty and integrity of politicians, the quality of the social, educational and cultural systems, the living environment as well as better future perspectives for their children. On the other hand, social life is generally considered to be more attractive in Tunisia than in Switzerland. While some of the Tunisians who were surveyed value the Swiss context for the freedom, range of choices and learning opportunities that it offers, which also allows them to develop personal and/or professional skills, others see Switzerland as little more than a place of work.

Generally, we see that most Tunisians in Switzerland hold a positive view of their country of residence, particularly with regard to employment, academic training, the quality of the social system, infrastructure and the living environment. However, many of them feel that it is difficult to do business and set up business there. They highlight the fact that this country does not give enough encouragement to migrants as potential entrepreneurs and vectors of commercial and cultural exchange. This feeling questions Swiss public policies on migration and diaspora, and more generally, it disputes the place and the role given to the migrants in this country. The possibility of integration, a tolerance of foreigners and access to a residence and work permit also received negative evaluations. These negative elements represent obstacles for the development of the investment and entrepreneurial projects of the members of the TCRS in Switzerland and in Tunisia.

\subsubsection{Access to the Labour Market and Entrepreneurial Activities}

Access to the jobs market plays a central role in the integration of the members of the TCRS in Switzerland as well as in their capacity to invest in their country of origin. The majority of the Tunisians surveyed are currently satisfied with their salary and their professional position. They believe that their professional position corresponds to their skills and qualifications. Nevertheless, some of them are experiencing difficulties to enter the labour market. A lack of professional experience, the limited social network, precarious residence permits, the obstacle posed by the language, limited employment possibilities for foreigners are some of the barriers in Switzerland that 
especially affect the least qualified members of the TCRS or those who have graduated recently.

Several participants highlighted Switzerland's limited interest in the professional insertion of young migrants who graduate from Swiss institutions. This perception deserves particular attention at two levels. On the one hand, the experiences accumulated by the Tunisians through their studies and their professional life in Switzerland represent valuable resources in terms of skills, professional networks and social capital that Tunisia could benefit from. On the other hand, in the current competitive world context, and given the weak probability of these graduates returning to Tunisia because of their propensity for mobility, countries with dynamic migratory policies could take advantage of the Swiss investment in the training of young Tunisian talent. This refers to the conservative Swiss policy on migration and more generally to Switzerland's poor valuation of the skills of migrants.

Several members of the TCRS, including a number of women, have created their own businesses. They are active in different sectors: taxi companies, beauty or hairdressing salons, cafés-bars, construction, solar energy, etc. However, we need to distinguish between two different types of entrepreneurial commitments: businesses started by highly-qualified Tunisians and those created by Tunisians with basic training and modest financial resources (mainly in the sales sector, the services sector and manual trades). Beyond these differences, the two models of entrepreneurs share a high level of initial risk and the support of their social networks which, in certain cases, compensate for the weakness of the initial investment. Some of them supplement their entrepreneurial activities, and consequently their income, with an extra job. In certain cases, these activities are linked to studies or training in Switzerland. The profile of the Tunisian entrepreneurs in Switzerland reveals a high capacity to innovate and take risks. This potential should be highlighted and taken into consideration when designing policy on migrant skills and entrepreneurship in Switzerland.

\subsubsection{Residency Status and the Sense of Belonging}

The collected data show a positive correlation between the length of time that the members of the TCRS stay in Switzerland and their sense of belonging to that country. However, this interdependence is not at the expense of ties in Tunisia. Their testimonies effectively reveal a sense of belonging as transnational actors to the two countries, or even to any other place where they have created ties (Levitt and GlickSchiller 2004; Kofman 2005). The multiple identities and belongings of the members of the TCRS are particularly reflected in the following comments:

I am also happy in Tunisia. Because I am Swiss-Tunisian, I therefore feel that I am in the two countries (a member of the TCRS).

For me, it would be difficult to return to Tunisia, mainly because there is no mixing there. In my case, I need to mix in order to live. It is difficult to live with just one's own nationality. I see myself as a citizen of the world (a member of the TCRS). 
Even though the members of the TCRS hold different kinds of residence permits, their formal resident status and their nationality/nationalities do not generally limit their sense of belonging to Tunisia or to Switzerland. In other words, even though their formal belonging could be created by the status that their nationality/nationalities or residence permit gives them, the attachment to their host country and their country of origin is built independently of this. Certain studies have shown that a migrant who lives permanently and who is integrated in a foreign country does not necessarily see a weakening of the bonds with the family and the community back in the country of origin (Portes et al. 2002). Our observations suggest that the feeling of belonging to Tunisia is very high among the members of the TCRS irrespective of their official residence permit or the duration of their stay abroad. The Tunisian identity allows them to identify with, and feel close to their country of origin. Even without living there, they maintain strong emotional, economic and/or professional bonds with Tunisia.

I have nothing against Switzerland; this is a personal challenge. I am more Swiss than Tunisian in terms of heart and mind, but I am a Tunisian of origin and I will remain a person of Tunisian origin (a member of the TCRS).

\subsection{Links and Impact on Local Development in Tunisia}

The majority of Tunisians have a prevailing interest in the regional and/or national development of Tunisia. Furthermore, their personal aspirations are linked to socioeconomic development in Tunisia, as we saw that the majority of Tunisians believe that their current activity could benefit their home country in various ways, which include: transferring know-how and capitalizing on their accumulated competences, participating in social grassroots cooperation projects that involve the local community, promoting trade and business links, entrepreneurial activities, and academic and scientific exchanges. Some Tunisians pointed to the possibility of contributing through physical return to their region of origin and encouraging ventures to deploy their accumulated skills once they go back. Their aspirations are clarified by a moral feeling of commitment and loyalty towards Tunisia.

The analysis of our observations has led us to recognise that the aspirations of Tunisians in Switzerland about how they engage with Tunisia depend on the particular characteristics of their individual social profiles (such as age, level of education, length of stay abroad, reasons for emigration, present activity) on the one hand, and on structural factors linked to the country environment that influence their opportunities to deploy the accumulated skills on the other. Consequently, the migrants' desire to contribute is mainly related to their personal profiles and objectives, their experiences in Switzerland and the opportunity structures offered by their home country. Most Tunisians associate their desire to contribute to Tunisian with the professional experiences and the training they have completed in the host countries. 
I think that as Tunisians, we must share the know-how of Switzerland, the skills we have acquired in Switzerland, for the benefit of Tunisia so that it can develop and rebuild (a member of the TCRS).

The strongest links that Tunisians have with their home country are through their families back home, including both immediate and extended family members, who are also an important source of information about the political situation and about suitable investment environments or other types of collaboration opportunities in Tunisia. Family ties and social networks provide Tunisians with the confidence that is necessary to launch entrepreneurial activities in Tunisia (Cassarino 2000). The families left behind provide significant support to help them accomplish their projects. Kinship links may be transformed into concrete engagements and actions, particularly in those cases where migration is seen as a strategy to improve the living conditions of a family. The geographical proximity of the two countries, Tunisia and Switzerland, allows Tunisians to visit their home country at least once a year. Furthermore, the aftermath of the revolution made it possible to reconstruct some of the links that were lost during the dictatorship and this has opened up new opportunities for engagement.

After the Revolution I was able to rebuild my contacts and personal relations, not only with my immediate family, but also with my extended family: cousins, uncles and aunts. I can also visit colleagues from my university days (a member of the TCRS).

We identified four specific vectors of engagement through which members of the TCRS participate in socioeconomic activities in Tunisia: financial transfers and investments, social remittances (Levitt 1998) in the form of social capital and knowledge transfers, philanthropy and humanitarian aid, and plans to return. Of these, financial transfers and investments came to the fore as the most specific material vector between migrants and their home country. We were able to observe how Tunisians who emigrated for economic reasons or those from a modest social background are the people most likely to send financial remittances on a regular basis. This observation finds resonance in the conclusions of other empirical studies, which illustrate the relation between the level of remitting and investing in the home country and the migrants' level of education (CODEV-EPFL et al. 2014). As far as Tunisians' investments are concerned, three main types of investments stood out from the data we gathered: purchasing land for agriculture or infrastructure, building a house, and creating a small or medium-size business. These investments pursue two major goals: ensuring adequate living conditions for migrants and their families in Tunisia, and preparing for a possible return.

I sent money to my personal Tunisian account. I am living abroad, but I also have to save a little so that I can go back with some money. Yes, God willing, I can stay for another five years, I will be able to have some money to allow me to buy a house in Tunisia (a member of the TCRS).

The study unveiled various individual investments, most of which were in the following economic sectors: information and communication, agriculture and forestry, real estate and administrative activities, construction, and scientific and technical activities. We were able to observe how Tunisians use the knowledge, and the 
technical and vocational skills they have acquired abroad to introduce new ideas, establish small businesses and improve business management in Tunisia. However, the likelihood of the Tunisian community reaping benefits from this depends on many factors that are subject to local conditions and structures making it easy to absorb these new skills, as well as existing resources and infrastructure, and to there being a sufficient responsiveness and welcome culture among the local community.

\subsection{Projections and Experiences of Tunisians Regarding Investment in Tunisia}

The accounts of the members of the TCRS highlight two peculiarities of the Tunisian context that are favourable to investment and entrepreneurial projects in spite of the dictatorship or the political instability after the revolution: these are the geographic proximity of the two countries and family ties, which is a main factor in terms of security and trust in Tunisia. Given the importance of these ties, the entrepreneurs from the TCRS tend to invest in their regions of origin. The testimonies we gathered reveal a lack of trust in the Tunisian authorities and low expectations of the Swiss and Tunisian authorities with regard to any project that might involve them.

The characteristics of the entrepreneurs of the TCRS as well as their projections, experiences and expectations towards entrepreneurship in Tunisia can be grouped into three sections: a) positive and negative projections, b) hampered or failed attempts and, c) investment in Tunisia from Switzerland, or after returning to the country.

\subsubsection{Positive or Negative Projections}

Those members of the TCRS with positive or negative projections about investing in Tunisia generally rely on their professional qualifications, experiences and skills acquired in Switzerland as well as on their family ties. The members of the TCRS have requirements regarding framework conditions (similar or close to those in Switzerland) for any investment or entrepreneurial project in Tunisia.

The "positive-minded" beautician

"I got my beautician's diploma with the idea of investing in Tunisia. With my European diploma, people know [that] well (...) I am going to be successful. The people think that a woman with a diploma from Europe is a professional. I gained respect with so many diplomas and so much work. That pleases me. I do not think that the political situation can influence my plan to invest there. I think that it should not be too complicated. You have to think positively. Otherwise, 
nobody will do anything and the country will remain as it is at the moment" (a member of the TCRS).

The "negative-minded" construction entrepreneur

"I would love to work back in Tunisia, I have a lot of experience. But I want to work there in the European way. There is always this fear of a lack of seriousness and corruption in Tunisia that holds me back" (a member of the TCRS).

\subsubsection{Hampered or Failed Attempts}

Hampered or failed attempts coincide with the investment experiences of the members of the TCRS in Tunisia during the Ben Ali regime and in the period since the revolution. There have been significant difficulties associated not only with political reasons (repression before the revolution and instability after it) but also with the structural, socio-economic and cultural barriers of the Tunisian context (for example, corruption, the lack of assistance to create businesses, bureaucratic delays, uncertainties, etc.). These difficulties have resulted in the businesses of some Tunisians going bankrupt while others regret their investment in Tunisia and abandon their business project. Despite the problems faced in failed attempts to associate with public institutions, other Tunisians have not lost hope in the possibility to generate innovative projects in their home country. However, as Minto-Coy's study (2011) of the diaspora's contribution to the Caribbean shows, failure to engage with the public and private sectors may compromise the effectiveness of individual or organised diaspora involvement by hindering any possible scaling-up activities with a development potential impact in the home country.

The bankrupt business

"The Central Bank and the customs administration said it was one of the best organised projects they had ever seen in Tunisia. I had a marvellous set-up. This "cash cow" started to work well and we were making some extraordinary lock mechanisms of our own, without any local credit facilities, which meant we could escape the clutches of Ben Ali. So, of course, as soon as they saw that I was starting to earn a little money and that I was paying the licencing authority, they felt they had to "get their bit". All my contracts contained a non-corruption clause. I was proud of that. I thought that I was going to be one of the first people to undertake a project of one's own in Tunisia. At some point, I felt that I was sheltered from... it was a rough time. I spent three painful years of my life. Following this failure and thanks to my research into 
mandates, I had an opportunity and I returned to Switzerland" (a member of the TCRS).

Regretting the investment made in Tunisia

"My business was established in a disadvantaged, sensitive and risky region of Tunisia. I didn't even get around to producing anything. My staff had to be let go. Today, I regret investing in Tunisia" (a member of the TCRS).

Abandoning the business project

"I wanted to invest in Tunisia and create a transport company. They rent coldchain vehicles, which is almost non-existent in Tunisia. We wanted to start with a pilot project in $(\mathrm{X})$ because it had a fishing port. We approached a leasing company to buy the first truck. We had to put up 30\% of personal capital, which we had. But the leasing company turned us down because we didn't have a transport agreement, and you have to purchase at least 10 trucks for that. We couldn't manage to gather the equity (30\%) for the 10 trucks. We wanted to start off small, and then expand if things went well. We encountered many administrative problems. Yet, I have experience as an entrepreneur in other countries. In order to encourage Tunisians abroad to invest, it is necessary to review the enterprise laws, which are made for "big companies". A young person cannot set up a business in Tunisia" (a member of the TCRS). Confidence in a better future

"One day, someone from the government contacted me: "Sir, you are known for your high skills and we would like to leverage them to establish solar energy projects in Tunisia". We developed the idea of a great value chain project around renewable energies validated by an internal commission. All of a sudden, the project started to wobble because the government weakened, the future was uncertain; the people were worried about their prospects. All was blocked at the administration level. Today, the project has not been totally forgotten; it is in the pipeline waiting until things become clearer at the institutional level. I was somewhat discouraged because of all the efforts and means invested. However, I think that Tunisia will see an incredible economic boost in the years to come. I may be one of the few ones saying this. But I do believe it" (a member of the TCRS).

\subsubsection{Investment in Tunisia from Switzerland or After Returning to the Country}

Several members of the TCRS confirm the importance of the professional experiences and skills they acquired in Switzerland as well as family ties for their entrepreneurial project in Tunisia. The experiences lived and the difficulties encountered by the entrepreneurs in Tunisia are many as the testimonies below illustrate. 
Investment from a distance

"The central idea was based on my experience in Switzerland. We created a help and advice service in Tunis. People can come to talk about their medical, financial or other problems, and we try to find a solution to them. We rented premises for this purpose. Two of my siblings are helping us. We need to have someone on site who we can trust. They work as volunteers" (a member of the TCRS).

Entrepreneurship involving a return to Tunisia

"After the revolution, we started out with a small catering workshop. We had six or seven employees at that time. After that, we opened our point of sale and we soon had 15 employees. Today we have 35 people working for us. We had many problems with recruiting and with maintaining quality. It was difficult to find qualified people who were prepared to work at the rhythm of a start-up and with the quality standards that we had imported from Europe. We had problems in terms of hygiene, as we had to provide training for everybody. We used the employment exchanges to recruit staff. We rarely found people who understood our needs. Labour and employment law is too rigid in Tunisia and thus unsuitable for start-ups. The banks are bad partners for businesses here. It was only after overcoming several problems and after waiting for several months that we managed to obtain some overdraft facilities. You have to pay bribes all the time. When the merchandise was blocked at customs, they wanted 1000 dinars to allow it through" (a member of the TCRS).

\subsection{Factors Influencing Engagement, and the Expectations of the Members of the TCRS Towards Tunisia}

\subsubsection{Constraining and Encouraging Factors}

The experiences of the TCRS and the examples of the activities presented above reveal the personal, structural (in Tunisia and in Switzerland) and behavioural restraints that can sometimes make it difficult to invest and create a business in Tunisia. Notwithstanding these restraints, there are certain encouraging factors that facilitate Tunisians' investments in their home country. Table 1 offers an overview of the constraining and encouraging factors.

The diversity of constraining and encouraging factors has an influence on the development possibilities of investment projects and the creation of companies by members of the TCRS, and this diversity also influences their mobility decisions. As with the findings of Carling et al. (2016), we could see that Tunisians rely on families and friends, social media and networks for information about the home country environment and this influences their mobility and entrepreneurship decisions. In 
Table 1 Factors influencing the investment and entrepreneurial projects of the TCRS in Tunisia

\begin{tabular}{l|l}
\hline Encouraging factors & Constraining factors \\
\hline $\begin{array}{l}\text { Emotional ties with Tunisia that result in high } \\
\text { incentives for development }\end{array}$ & $\begin{array}{l}\text { A lack of support for diaspora initiatives from } \\
\text { the Tunisian and Swiss governments }\end{array}$ \\
\hline Strong family bonds and support & $\begin{array}{l}\text { Limited financial funding for diaspora } \\
\text { initiatives }\end{array}$ \\
\hline Skills and expertise of the diaspora & $\begin{array}{l}\text { A lack of trust in the Tunisian public } \\
\text { institutions }\end{array}$ \\
\hline $\begin{array}{l}\text { Social and professional integration in } \\
\text { Switzerland }\end{array}$ & Political instability in Tunisia \\
\hline $\begin{array}{l}\text { Students and young professionals are open to } \\
\text { opportunities }\end{array}$ & $\begin{array}{l}\text { A lack of receptiveness from the local } \\
\text { community in Tunisia }\end{array}$ \\
\hline $\begin{array}{l}\text { Geographical proximity between Switzerland } \\
\text { and Tunisia }\end{array}$ & $\begin{array}{l}\text { Vulnerability linked to residence permits in } \\
\text { Switzerland }\end{array}$ \\
\hline $\begin{array}{l}\text { The renowned quality of Swiss education and } \\
\text { training systems }\end{array}$ & $\begin{array}{l}\text { Difficulties to create businesses in Tunisia } \\
\text { because of structural, socio-economic and } \\
\text { cultural barriers }\end{array}$ \\
\hline $\begin{array}{l}\text { The scientists and researchers are well } \\
\text { established in Switzerland }\end{array}$ & $\begin{array}{l}\text { Rigorous framework conditions in Tunisia for } \\
\text { investing and establishing entrepreneurial } \\
\text { projects }\end{array}$ \\
\hline Associative activities and community actions & $\begin{array}{l}\text { Difficulties to find qualified and competent } \\
\text { local staff in Tunisia }\end{array}$ \\
\hline $\begin{array}{l}\text { Skills, networks and social capital developed in } \\
\text { Switzerland and in other countries are ready to } \\
\text { be deployed in Tunisia }\end{array}$ & $\begin{array}{l}\text { Absence of supportive conditions to allow } \\
\text { qualified members of the diaspora to launch } \\
\text { initiatives and projects }\end{array}$ \\
\hline $\begin{array}{l}\text { Internet and social media } \\
\begin{array}{l}\text { The diaspora's dynamism, creativity and search } \\
\text { for innovation }\end{array}\end{array}$ & $\begin{array}{l}\text { Divisions between the associations of the } \\
\text { TCRS }\end{array}$ \\
\hline $\begin{array}{l}\text { Lack of time } \\
\text { and }\end{array}$ &
\end{tabular}

addition, the experiences of Tunisians show how significant changes need to be made to the political, economic and cultural structures to make it possible to harness migrants' resources and translate them into investment and entrepreneurship endeavours with positive effects for the home country. This illustrates the importance of paying sufficient attention to the local cultural and political aspects in the present discussion on diaspora remittances and business creation in the home country (Gillespie et al. 1999; Nielsen and Riddle 2007; Nkongolo-Bakenda and Chrysostome 2013; Carling 2014).

\section{Conclusions}

This empirical case study on Tunisian migration in the post-revolution context shows that the members of the TCRS are potential actors for investment and entrepreneurial projects in Tunisia thanks to the richness of their multi-site migratory paths and their international social networks, as well as their savings and professional and technical 
skills, most of which have been acquired in Switzerland. Moreover, this community feels a strong motivation to contribute to the development of the country of origin, and effectively its members are very attached to Tunisia.

The spontaneous individual-based actions they undertake in their localities of origin reveal their entrepreneurial determination through investment, business startups and job creation outside the framework of established supportive public policies, thereby highlighting the opportunities and constraints of the diaspora option. However, mobilising the skills and resources of the diaspora and encouraging their home country engagement does not depend solely on migrants' personal profiles, training, professional activities or even their motivation, but rather it depends equally on the environment and the opportunities offered by both the host country and the country of origin.

The study reveals significant hindrances on the development of investment and entrepreneurial projects by members of the TCRS in Switzerland and Tunisia. The TCRS members are generally satisfied with living and employment conditions in Switzerland. However, they consider the Swiss context to be a difficult one in which to do business or start up a business, and too restrictive in terms of residence and work permits. Yet, Tunisian entrepreneurs in Switzerland show a high level of dynamism, creativity and desire for innovation.

As far as the experiences of the TCRS in Tunisia are concerned, these provide an insight into the constraining and encouraging factors that are linked to entrepreneurial activities in the country. On the one hand, the entrepreneurs at the heart of the TCRS rely on the professional qualifications, savings, experiences and skills they have acquired in Switzerland or elsewhere, the geographic proximity between Switzerland and Tunisia, and their family ties. On the other hand, a lack of trust in Tunisian public institutions, structural, socioeconomic and cultural barriers that hinder the creation of companies in Tunisia and political instability are all important constraining factors. The potential of TCRS members as development actors highlighted by the results of this study could open a path for innovative public policy design in both countries, encouraging migrants' skills and entrepreneurial projects and facilitating their mobility between Switzerland and Tunisia.

\section{References}

Agunias DR (2006) Remittances and development: trends, impacts and policy options. A review of the literature. MPI, Washington, DC

Agunias DR, Newland K (2012) Developing a road map for engaging diasporas in development. A handbook for policymakers and practitioners in home and host countries. IOM and MPI, Washington, DC

Bordes Benayoun C, Schnapper D (2006) Diasporas et nations. Odile Jacob, Paris

Boubakri H (2013) Revolution and international migration in Tunisia. Robert Schuman Centre of Advanced Studies/European University Institute, Florence

Bourdieu P (1986) The forms of social capital. In: Richardson JG (ed) Handbook of theory and research for the sociology of education. Greenwood Press, New York 
Brinkerhoff JM (ed) (2008) Diaspora and development: exploring the potential. Lynne Rienner Publishers, London

Carling J (2014) Scripting remittances: making sense of money transfers in transnational relationships. Int Migr Rev 48(1):218-262

Carling J et al (2016) Possibilities and realities of return migration. PRIO, Oslo

Carrera S, Den Hertog L, Parkin J (2013) The Arab Spring and EU's immigration policy: a critical sociology on the global approach to migration and mobility. Middle East Institute, Washington, DC

Cassarino JP (2000) Tunisian new entrepreneurs and their past experiences in migration in Europe. In: Resource mobilization, networks, and hidden disaffection. Ashgate, Aldershot

CODEV-EPFL, IDSK, JNU, ILO (2014) Migration, scientific diasporas and development: impact of skilled return migration on development in India. Final research report. Cahier de la Coopération no. 8. CODEV-EPFL, Lausanne

Cohen R (1997) Global diasporas: an introduction. UCL Press, London

Crush J et al (2013) Divided diasporas: Southern Africans in Canada. CIGI/SAMP, Waterloo

Di Bartolomeo A, Fakhoury T, Perrin D (2010) Tunisia. CARIM-Migration Profile. Robert Schuman Center of Advanced Studies/European University Institute, Florence

Elo M, Riddle L (2016) Understanding diaspora investments. In: Elo M, Riddle L (eds) Diaspora business. Interdisciplinary Press, Oxford, pp 13-28

Faist T, Fauser M, Kivisto P (2011) The migration and development nexus: a transnational perspective. Palgrave McMillan, New York

Galetto V (2011) Migration and productive investment: a conceptual framework. In: Plaza S, Ratha D (eds) Diaspora for development in Africa. World Bank, Washington, DC, pp 238-328

Gillespie K, Riddle L, Sayre E, Sturges D (1999) Diaspora interest in homeland investment. J Int Bus Stud 30(3):623-634

Hercog M (2014) Migration-development links in selected European destination countries. In: Tejada G, Bhattacharya U, Khadria B, Kuptsch C (eds) Indian skilled migration and development. To Europe and back. Springer, New Delhi, pp 71-86

IOM (International Organisation for Migration), UNDP (United Nations Development Programme) (2015) White Paper: Mainstreaming migration into local development planning and beyond. IOM and JMDI, Geneva and Brussels

JMDI (Joint Migration and Development Initiative) (2015) Toolbox on migration and local development. JMDI and UNDP, Brussels

Kofman E (2005) Citizenship, migration and the reassertion of national identity. Citizen Stud 9 (5):453-467

Levitt P (1998) Social remittances: migration-driven local-level forms of cultural diffusion. Int Migr Rev 32(4):926-948

Levitt P, Glick-Schiller N (2004) Conceptualizing simultaneity: a transnational social field perspective on society. Int Migr Rev 38(3):1002-1039

Meyer J-B (2001) Network approach versus brain drain: lessons from the diaspora. Int Migr 39 (5): $91-110$

Meyer J-B (2014) Diaspora networks and high skilled mobility: lessons of experience from Latin America

Minto-Coy I (2011) Beyond remittancing. An investigation on the role of ICTs in facilitating and extending the diaspora's contribution to the Caribbean. Can Foreign Policy J 17(2):129-141

Minto-Coy I (2016a) The role of diasporas in the growth and internationalisation of business in countries of origin. In: Elo M, Riddle L (eds) Diaspora business. Interdisciplinary Press, Oxford, pp 29-43

Minto-Coy I (2016b) Diaspora engagement for development in the Caribbean. In: Chikanda A, Crush J, Walton-Roberts M (eds) Diasporas, development and governance, Global migration issues. Springer, Switzerland, pp 121-139

Newland K (ed) (2010) Diasporas. New partners in global development policy. MPI, Washington, DC

Newland K, Tanaka H (2010) Mobilizing diaspora entrepreneurship for development. In: Newland $\mathrm{K}$ (ed) Diasporas. New partners in global development policy. MPI, Washington, DC, pp 25-59 
Nielsen T, Riddle L (2007) Why Diasporas invest in the homeland: a conceptual model of motivation. George Washington University, Washington, DC

Nkongolo-Bakenda J-M, Chrysostome EV (2013) Engaging diasporas as international entrepreneurs in developing countries: in search of determinants. J Int Entrep 11(1):30-64

Portes A (1998) Social capital. Its origins and applications in modern sociology. Annu Rev Sociol 24:1-24

Portes A (2001) The debates and significance of immigrant transnationalism. Glob Netw 1 (3):181-194

Portes A, Yiu J (2013) Entrepreneurship, transnationalism and development. Migr Stud 1(1):75-95

Portes A, Haller W, Guarnizo L (2002) Transnational entrepreneurs: an alternative form of immigrant economic adaptation. Am Sociol Rev 67(2):278-298

Ratha D (2009) Remittances in development. Financ Dev 46(4):30-31

SEDESOL (Secretaria de Desarrollo Social) (2014) Diagnostico del Programa 3x1 para Migrantes. SEDESOL, Mexico. http://www.3x1.sedesol.gob.mx/documentacion/2014/diag.pdf

Seeberg P (2014) Mobility partnerships and the EU, Part II: The cases of Libya, Morocco and Tunisia. Center for Contemporary and Middle East Studies, Odense

SEMTE (Secretary of State for Migration and Tunisians Abroad) (2013) Vers une stratégie nationale en matière de migration et des Tunisiens à l'étranger

Sheffer G (ed) (1986) Diasporas in international relations. St Martin's Press, New York

Siddiqui Z, Tejada G (2014) Development and highly skilled migrants; perspective from the Indian diaspora and returnees. Int Dev Policy 6(1)

Smith L (2011) Business as usual? Urban actors and transnational investments in Accra, Ghana. In: Faist $\mathrm{T}$ et al (eds) The migration and development nexus. A transnational perspective. Palgrave McMillan, New York, pp 104-133

Tejada G (2012) Mobility, knowledge and cooperation: scientific diasporas as agents of development. Migr Dev 10(18):59-92

Tejada G, Garcia Delahaye S (2014) La Communauté Tunisienne Résidente en Suisse (CTRS): Tour d'horizon

Tejada G, Bhattacharya U, Khadria B, Kuptsch C (eds) (2014) Indian skilled migration and development. To Europe and back. Springer, New Delhi

Vaaler P (2011) Immigrant remittances and the venture investing environment of developing countries. J Int Bus Stud 42:1121-1149

Varzari V, Tejada G, Porcescu S, Bolay J-C (eds) (2014) Skilled migration and development practices: Republic of Moldova and the countries of South East Europe. ASM, Chisinau

Vertovec S (2001) Transnationalism and identity. J Ethn Migr Stud 27(4):573-582

Wickramasekara P (2010) Transnational communities: reflections on definitions, measurements and contributions. In: Tejada G, Bolay J-C (eds) Scientific diasporas as development partners. Skilled migrants from Colombia, India and South Africa in Switzerland: empirical evidence and policy responses. Peter Lang, Bern, pp 137-178

Zekri ABH (2004) Les politiques migratoires, les institutions compétentes et leur environnement en Tunisie. Robert Schuman Centre of Advanced Studies/European University Institute, Florence 